\title{
H1-1 Gene
}

National Cancer Institute

\section{Source}

National Cancer Institute. H1-1 Gene. NCI Thesaurus. Code C126423.

This gene is involved in both DNA binding and nucleosome formation. 